\title{
Functionalization of $\boldsymbol{N}$-arylglycine esters: electrocatalytic access to $\mathrm{C}-\mathrm{C}$ bonds mediated by $\boldsymbol{n}-\mathrm{Bu}_{4} \mathrm{NI}$
}

\author{
Mi-Hai Luo ${ }^{1}$, Yang-Ye Jiang ${ }^{1}$, Kun Xu ${ }^{1}$, Yong-Guo Liu ${ }^{2}$, Bao-Guo Sun ${ }^{2}$ \\ and Cheng-Chu Zeng ${ }^{* 1}$
}

\author{
Full Research Paper \\ Address: \\ ${ }^{1}$ Beijing Key Laboratory of Environmental and Viral Oncology, College \\ of Life Science \& Bioengineering, Beijing University of Technology, \\ Beijing 100124, China and ${ }^{2}$ Beijing Key Laboratory of Flavor \\ Chemistry, Beijing Technology and Business University, Beijing \\ 100048, China \\ Email: \\ Cheng-Chu Zeng* - zengcc@bjut.edu.cn \\ * Corresponding author \\ Keywords: \\ C-C formation; electrochemical oxidative functionalization; $n-\mathrm{Bu}_{4} \mathrm{NI}$; \\ redox catalyst
}

\author{
Beilstein J. Org. Chem. 2018, 14, 499-505. \\ doi:10.3762/bjoc. 14.35 \\ Received: 17 November 2017 \\ Accepted: 13 February 2018 \\ Published: 22 February 2018 \\ This article is part of the Thematic Series "Electrosynthesis II". \\ Guest Editor: S. R. Waldvogel \\ (c) 2018 Luo et al.; licensee Beilstein-Institut. \\ License and terms: see end of document.
}

\begin{abstract}
An efficient electrocatalytic functionalization of $N$-arylglycine esters is reported. The protocol proceeds in an undivided cell under constant current conditions employing the simple, cheap and readily available $n$ - $\mathrm{Bu}_{4} \mathrm{NI}$ as the mediator. In addition, it is demonstrated that the mediated process is superior to the direct electrochemical functionalization.
\end{abstract}

\section{Introduction}

The oxidative cross dehydrogenative coupling (CDC) of two $\mathrm{C}-\mathrm{H}$ bonds has emerged as an versatile and powerful strategy for forming new $\mathrm{C}-\mathrm{C}$ bonds in organic chemistry due to its step and atom economic characteristic as well as avoiding the prefunctionalization of substrates [1-5]. Most of the $\mathrm{CDC}$ reactions occur between the benzylic $\mathrm{C}-\mathrm{H}$ bonds and $\alpha-\mathrm{C}-\mathrm{H}$ bonds adjacent to a heteroatom ( $\mathrm{N}$ or O) [6-10]. However, the oxidative $\mathrm{C}-\mathrm{C}$ formation of secondary amines, especially amino acids has been more important for studying properties and functions of natural and non-natural amino acids [11]. Consequently, efficient and selective construction of $\mathrm{C}-\mathrm{C}$ bonds of amino acids has always been paid much attention in industrial and academic setting and many advances have been made [1217]. Li et al. first reported the functionalization of glycine derivatives with malonates using a stoichiometric quantity of $\mathrm{Cu}(\mathrm{OAc})_{2}$ as catalyst and oxidant [12]. Later on, arylation, vinylation and alkynylation of glycine derivatives were also accomplished by the same group (Scheme 1) [13]. Using the $\mathrm{Cu}(\mathrm{OAc})_{2}$ /pyrrolidine dual catalysts system, Huang developed the oxidative cross coupling of glycine derivatives with acetone in the presence of TBHP or DDQ as terminal oxidants [14]. The protocol was also extended to reactions with 2-alkylquinoline 


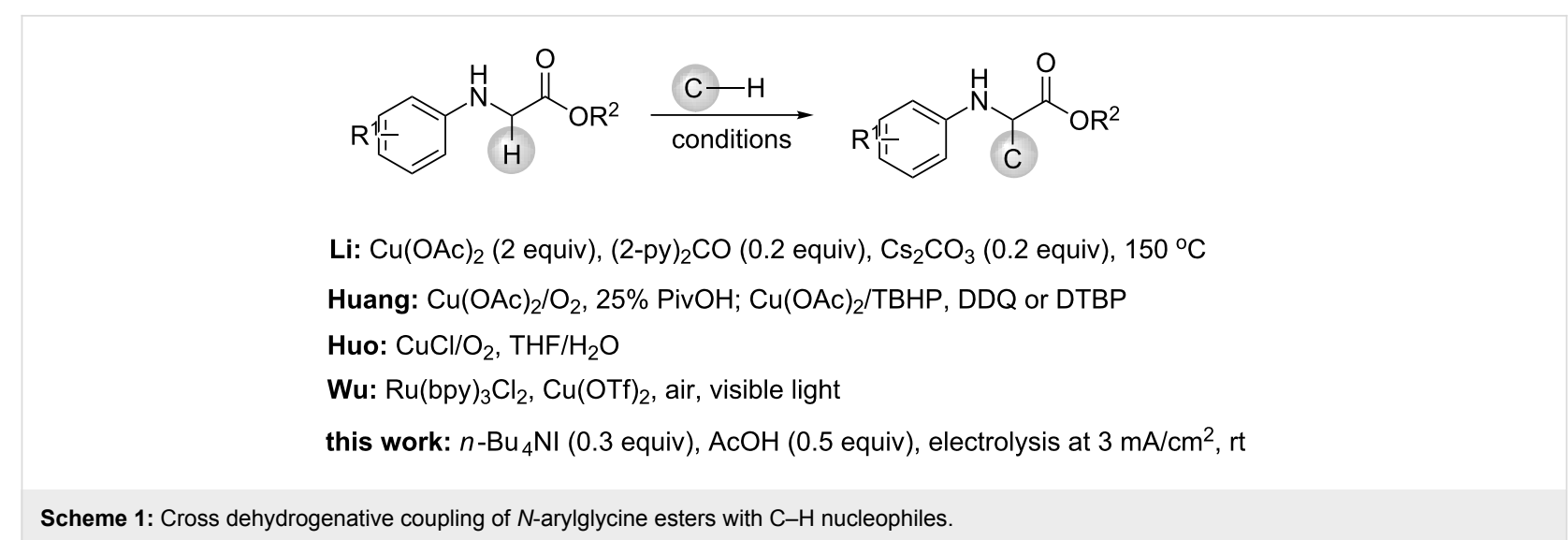

Scheme 1: Cross dehydrogenative coupling of $\mathrm{N}$-arylglycine esters with $\mathrm{C}-\mathrm{H}$ nucleophiles.

[15] and phenols [16] using $\mathrm{O}_{2}$ and di-tert-butyl peroxide (DTBP) as oxidant, respectively (Scheme 1). A CuCl-catalyzed oxidative cross coupling of glycine derivatives with indoles has been developed by Hou et al., wherein simple copper salts were used as catalysts and oxygen as the co-oxidant (Scheme 1) [17].

Alternatively, photocatalytic versions of CDC reactions of glycine derivatives with C-nucleophiles were also developed $[18,19]$. For example, combining the visible light catalyst $\mathrm{Ru}(\text { bpy })_{3} \mathrm{Cl}_{2}$, and the transition metal catalyst $\mathrm{Cu}(\mathrm{OTf})_{2}, \mathrm{Wu}$ and co-workers achieved aerobic oxidative coupling of secondary amines with $\beta$-keto esters to form $\mathrm{C}\left(\mathrm{sp}^{3}\right)-\mathrm{C}\left(\mathrm{sp}^{3}\right)$ bonds (Scheme 1) [18].

Although much advance has been made for the functionalization of glycine derivatives, most of these strategies mentioned above require stoichiometric or excess amounts of chemical oxidants and transition metal (photo)catalysts. The utilization of stoichiometric or excess amounts of chemical oxidants results in producing waste, which is not atomic economically and environmentally benign. In addition, over-oxidation of products likely occurs in the presence of excess amounts of oxidant. On the other hand, the toxicity of residual traces of transition metal (photo)catalyst in products is also highly concerned. Consequently, metal-free and environmentally friendly oxidative $\mathrm{C}-\mathrm{C}$ bond formation is highly desired.

Electrochemistry has proved to be an environmentally benign method to achieve the formation of a new chemical bond and a functional group conversion by using electrons as redox reagent rather than terminal chemicals [20-27]. In this context, we have applied simple halide ions as redox catalysts to achieve electrochemical $\mathrm{C}-\mathrm{H}$ bond functionalization, leading to the formation of new $\mathrm{C}-\mathrm{C}, \mathrm{C}-\mathrm{N}, \mathrm{C}-\mathrm{O}$ and $\mathrm{C}-\mathrm{S}$ bonds [28-31]. Herein, we report the electrochemical $\alpha-\mathrm{C}-\mathrm{H}$ functionalization of $N$-arylglycine esters with $\mathrm{C}-\mathrm{H}$ nucleophiles using $n$ - $\mathrm{Bu}_{4} \mathrm{NI}$ as redox catalyst (Scheme 1 ). The chemistry was performed in an undi- vided cell under constant current electrolysis. It was observed that $n$ - $\mathrm{Bu}_{4} \mathrm{NI}$ promotes the reaction dramatically and higher yields of $\alpha$-functionalized products were afforded compared with the direct electrolysis.

\section{Results and Discussion}

Initially, $N$-arylglycine ester $\mathbf{1 a}$ and $\mathrm{C}-\mathrm{H}$ nucleophile 1,3,5trimethoxybenzene (2a) were chosen as model compounds to optimize the electrolytic conditions. As shown in Table 1, when constant current electrolysis (CCE) of $\mathbf{1 a}$ and $\mathbf{2 a}$ was performed in an undivided cell equipped with $0.1 \mathrm{M} \mathrm{LiClO}_{4}$ in $\mathrm{CH}_{3} \mathrm{CN}$ in the presence of $\mathrm{AcOH}$ using two graphite plates as anode and cathode, the desired product 3 aa was isolated in $27 \%$ yield (Table 1, entry 1). Replacing $\mathrm{CH}_{3} \mathrm{CN}$ by other solvents, such as methanol, ethanol or $\mathrm{CH}_{2} \mathrm{Cl}_{2}$ failed to improve the reaction efficiency and only trace amounts of $\mathbf{3 a a}$ were detected (Table 1, entries 2-4). Further solvent screening disclosed that a 1:2 ratio of $\mathrm{CH}_{3} \mathrm{CN}$ and $\mathrm{CH}_{2} \mathrm{Cl}_{2}$ was better, giving $3 \mathbf{a a}$ in $66 \%$ yield (Table 1, entries 5 and 6). Exploring the influence of current density on the $\mathrm{CDC}$ reaction indicated that $3 \mathrm{~mA} / \mathrm{cm}^{2}$ was suitable; lower or higher current density led to a slightly lower yields of 3aa (entry 5, vs entries 7 and 8). It was observed that the additive plays an important role. Among several additives examined, AcOH was proved to be the best, although TFA also gave comparable yields of 3aa (Table 1, entries 5 and 11-13), whereas, it gave only $38 \%$ yield of 3 aa when the reaction was carried out in the absence of AcOH (Table 1, entry 9). Investigation of the anode proved that graphite was superior to Pt and DSA (Dimensionally Stable Anode, Table 1, entries 14 and 15). Finally, to further improve the reaction efficiency, several halide-containing mediators as redox catalyst were evaluated. To our delight, when $n$ - $\mathrm{Bu}_{4} \mathrm{NI}$ was utilized as a redox catalyst, the yield of 3aa increased to $81 \%$ (Table 1, entries 16-19).

On the basis of the screening of reaction conditions, we could conclude that the electrocatalytic oxidative coupling should be performed in a mixed solution of $\mathrm{CH}_{3} \mathrm{CN}$ and $\mathrm{CH}_{2} \mathrm{Cl}_{2}$ 
Table 1: Optimization of reaction conditions ${ }^{a}$<smiles>CCOC(=O)CNc1ccc(C)cc1</smiles>

1a<smiles>COc1cc(OC)cc(OC)c1</smiles>

2a

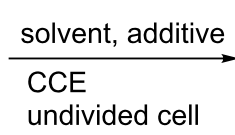

undivided cell<smiles>CCOC(=O)C(Nc1ccc(C)cc1)c1c(OC)cc(OC)cc1OC</smiles>

\begin{tabular}{|c|c|c|c|c|c|c|}
\hline entry & solvent & mediator (equiv) & $J\left(\mathrm{~mA} / \mathrm{cm}^{2}\right)$ & additive (equiv) & cathode/anode & yield $(\%)^{b}$ \\
\hline 1 & $\mathrm{CH}_{3} \mathrm{CN}$ & $-^{c}$ & 3 & $\mathrm{AcOH}(0.5)$ & $\mathrm{C} / \mathrm{C}$ & 27 \\
\hline 2 & $\mathrm{MeOH}$ & $-^{c}$ & 3 & $\mathrm{AcOH}(0.5)$ & $\mathrm{C} / \mathrm{C}$ & trace \\
\hline 3 & EtOH & $-^{c}$ & 3 & $\mathrm{AcOH}(0.5)$ & $\mathrm{C} / \mathrm{C}$ & trace \\
\hline $4^{\mathrm{d}}$ & $\mathrm{CH}_{2} \mathrm{Cl}_{2}$ & $-^{c}$ & 3 & $\mathrm{AcOH}(0.5)$ & $\mathrm{C} / \mathrm{C}$ & trace \\
\hline 5 & $\mathrm{CH}_{3} \mathrm{CN} / \mathrm{CH}_{2} \mathrm{Cl}_{2}(1: 2)$ & $-^{c}$ & 3 & $\mathrm{AcOH}(0.5)$ & $\mathrm{C} / \mathrm{C}$ & 66 \\
\hline 6 & $\mathrm{CH}_{3} \mathrm{CN} / \mathrm{CH}_{2} \mathrm{Cl}_{2}(2: 1)$ & $-^{c}$ & 3 & $\mathrm{AcOH}(0.5)$ & $\mathrm{C} / \mathrm{C}$ & 56 \\
\hline 7 & $\mathrm{CH}_{3} \mathrm{CN} / \mathrm{CH}_{2} \mathrm{Cl}_{2}(1: 2)$ & $-^{c}$ & 1 & $\mathrm{AcOH}(0.5)$ & $\mathrm{C} / \mathrm{C}$ & 47 \\
\hline 8 & $\mathrm{CH}_{3} \mathrm{CN} / \mathrm{CH}_{2} \mathrm{Cl}_{2}(1: 2)$ & $-^{c}$ & 5 & $\mathrm{AcOH}(0.5)$ & $\mathrm{C} / \mathrm{C}$ & 50 \\
\hline 9 & $\mathrm{CH}_{3} \mathrm{CN} / \mathrm{CH}_{2} \mathrm{Cl}_{2}(1: 2)$ & $-^{c}$ & 3 & $\mathrm{AcOH}(0.0)$ & $\mathrm{C} / \mathrm{C}$ & 38 \\
\hline 10 & $\mathrm{CH}_{3} \mathrm{CN} / \mathrm{CH}_{2} \mathrm{Cl}_{2}(1: 2)$ & $-^{c}$ & 3 & $\mathrm{AcOH}(1.0)$ & $\mathrm{C} / \mathrm{C}$ & 56 \\
\hline 11 & $\mathrm{CH}_{3} \mathrm{CN} / \mathrm{CH}_{2} \mathrm{Cl}_{2}(1: 2)$ & $-^{c}$ & 3 & TFA (0.5) & $\mathrm{C} / \mathrm{C}$ & 60 \\
\hline 12 & $\mathrm{CH}_{3} \mathrm{CN} / \mathrm{CH}_{2} \mathrm{Cl}_{2}(1: 2)$ & $-^{c}$ & 3 & $\mathrm{H}_{2} \mathrm{SO}_{4}(0.5)$ & $\mathrm{C} / \mathrm{C}$ & 13 \\
\hline 13 & $\mathrm{CH}_{3} \mathrm{CN} / \mathrm{CH}_{2} \mathrm{Cl}_{2}(1: 2)$ & $-^{c}$ & 3 & $\mathrm{Na}_{2} \mathrm{CO}_{3}(0.5)$ & $\mathrm{C} / \mathrm{C}$ & 40 \\
\hline 14 & $\mathrm{CH}_{3} \mathrm{CN} / \mathrm{CH}_{2} \mathrm{Cl}_{2}(1: 2)$ & $-^{c}$ & 3 & $\mathrm{AcOH}(0.5)$ & $\mathrm{C} / \mathrm{Pt}$ & 48 \\
\hline 15 & $\mathrm{CH}_{3} \mathrm{CN} / \mathrm{CH}_{2} \mathrm{Cl}_{2}(1: 2)$ & $-^{c}$ & 3 & $\mathrm{AcOH}(0.5)$ & C/DSA & 41 \\
\hline 16 & $\mathrm{CH}_{3} \mathrm{CN} / \mathrm{CH}_{2} \mathrm{Cl}_{2}(1: 2)$ & $n-\mathrm{Bu}_{4} \mathrm{NI}(0.3)$ & 3 & $\mathrm{AcOH}(0.5)$ & $\mathrm{C} / \mathrm{C}$ & 81 \\
\hline 17 & $\mathrm{CH}_{3} \mathrm{CN} / \mathrm{CH}_{2} \mathrm{Cl}_{2}(1: 2)$ & $n-\mathrm{Bu}_{4} \mathrm{NBr}(0.3)$ & 3 & $\mathrm{AcOH}(0.5)$ & $\mathrm{C} / \mathrm{C}$ & 48 \\
\hline 18 & $\mathrm{CH}_{3} \mathrm{CN} / \mathrm{CH}_{2} \mathrm{Cl}_{2}(1: 2)$ & $\mathrm{NH}_{4} \mathrm{l}(0.3)$ & 3 & $\mathrm{AcOH}(0.5)$ & $\mathrm{C} / \mathrm{C}$ & 54 \\
\hline 19 & $\mathrm{CH}_{3} \mathrm{CN} / \mathrm{CH}_{2} \mathrm{Cl}_{2}(1: 2)$ & $\mathrm{NH}_{4} \mathrm{Br}(0.3)$ & 3 & $\mathrm{AcOH}(0.5)$ & $\mathrm{C} / \mathrm{C}$ & 20 \\
\hline
\end{tabular}

${ }^{a}$ Conditions: $1 \mathrm{a}(1.0 \mathrm{mmol}), \mathbf{2 a}(1.2 \mathrm{mmol})$ in $15 \mathrm{~mL}$ solution, $\mathrm{LiClO}_{4}(0.1 \mathrm{M})$, room temperature, electrode $\mathrm{C}$ represents graphite plate. ${ }^{\mathrm{b}} / \mathrm{solated}$ yield. ${ }^{c}$ Without mediator. ${ }^{d} n-B_{4} \mathrm{NBF}_{4}$ was used as supporting electrolyte.

$(\mathrm{v} / \mathrm{v}=1: 2)$, in the presence of $n$ - $\mathrm{Bu} 4 \mathrm{NI}(30 \mathrm{~mol} \%)$ as the mediator, $\mathrm{AcOH}(50 \mathrm{~mol} \%)$ as the additive and using graphite plate as electrodes under constant current at $3 \mathrm{~mA} / \mathrm{cm}^{2}$. With the optimized conditions in hand, we then investigated the scope of $N$-arylglycine esters in the reaction with $2 \mathbf{a}$. As a comparison, direct electrochemical coupling of $N$-arylglycine esters with 2a was also performed. As shown in Scheme 2, substituents including either electron-donating groups (such as methyl and methoxy) or electron-withdrawing groups $\left(\mathrm{Cl}, \mathrm{Br}\right.$ and $\left.\mathrm{CF}_{3}\right)$ in the 4-position of the aryl group were tolerated and gave moderate to good yields of $\mathbf{3 b a}-\mathbf{3 e a}$ (61-69\% yields), whereas, only $47-58 \%$ yields of the desired $\mathbf{3 b a}-\mathbf{3 e a}$ were isolated under the direct electrolytic conditions. However, $\mathbf{3}$ fa was afforded in $39 \%$ and $12 \%$ yields, respectively, when the electrochemical reaction was performed in the presence or absence of $n$-Bu $\mathrm{Bu}_{4} \mathrm{NI}$ as the redox catalyst. The reason for the low yield of $\mathbf{3 f a}$ is not clear yet. Steric factors seem to play an important role in the electrochemical CDC reaction of $N$-arylglycine esters with 2a. When the methyl group was situated at 2- or 3-position of the aniline, instead of in the 4-position, the corresponding products 3ga and 3ha were afforded in 36\% and $27 \%$ yields, respectively. However, 3ga and 3 ha were isolated in $14 \%$ and $11 \%$ yields, respectively, under the direct electrolytic conditions. In the cases of $N$-arylglycine methyl ester $1 \mathbf{i}$ and $N$-arylglycine benzyl ester $\mathbf{1} \mathbf{j}$, the electrocatalytic functionalization afforded excellent yields of $\mathbf{3 i a}(76 \%)$ and $\mathbf{3 j a}(84 \%)$, whereas, less efficiency (40-43\% yields) was observed without the assistance of $n-\mathrm{Bu}_{4} \mathrm{NI}$.

Next, the reactivity of different $\mathrm{C}-\mathrm{H}$ nucleophiles was also investigated. As shown in Scheme 3, $\beta$-keto ester and malonates worked well to afford the desired products $\mathbf{3 a b}-\mathbf{3 a d}$ in moderate yields. In addition, naphthanols were also compatible in this transformation, giving the corresponding products 3ae-3ag in good yields. Notably, when styrene and 1-ethynylbenzene were subjected to reaction with 1a under the standard indirect electrolytic conditions, quinoline-2-carboxylate 3ah was isolated in $64 \%$ and $58 \%$ yield, respectively. Substituted styrenes and 1-ethynylbenzene were also tolerated well, giving corresponding products $\mathbf{3 a i}-\mathbf{3 a j}$ in $45-50 \%$ yields. The formations of 


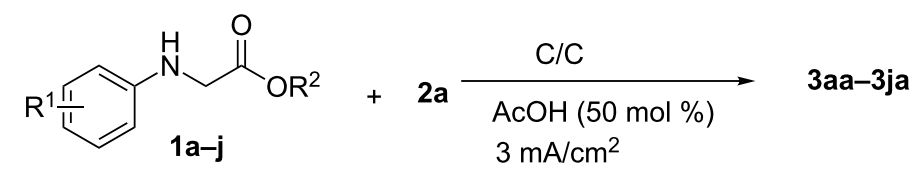<smiles>CCOC(=O)C(Nc1ccc(C)cc1)c1c(OC)cc(OC)cc1OC</smiles>

3aa $81 \%(66 \%)$<smiles>CCOC(=O)C(Nc1ccc(C(F)(F)F)cc1)c1c(OC)cc(OC)cc1OC</smiles>

3ea $65 \%$ (58\%)<smiles>CCOC(=O)C(Nc1ccc(OC)cc1)c1c(OC)cc(OC)cc1OC</smiles>

3ba $69 \%$ (49\%)<smiles>CCOC(=O)C(Nc1ccccc1)c1c(OC)cc(OC)cc1OC</smiles>

$3 \mathrm{fa} 39 \%(12 \%)$<smiles>CCOC(=O)C(Nc1ccc(Br)cc1)c1c(OC)cc(OC)cc1OC</smiles>
3ca $61 \%(47 \%)$<smiles>CCOC(=O)C(Nc1ccccc1C)c1c(OC)cc(OC)cc1OC</smiles>

3ga $36 \%$ (14\%)<smiles>CCOC(=O)C(Nc1ccc(Cl)cc1)c1c(OC)cc(OC)cc1OC</smiles>

3da $63 \%(48 \%)$<smiles>CCOC(=O)C(Nc1cccc(C)c1)c1c(OC)cc(OC)cc1OC</smiles>

3ha $27 \%(11 \%)$<smiles>COC(=O)C(Nc1ccc(C)cc1)c1c(OC)cc(OC)cc1OC</smiles>

3ia $76 \%(43 \%)$<smiles>COc1cc(OC)c(C(Nc2ccc(C)cc2)C(=O)OCc2ccccc2)c(OC)c1</smiles>

$3 \mathbf{j a} 84 \%(40 \%)$

Scheme 2: Electrochemical CDC reaction of $2 \mathrm{a}$ and various $\mathrm{N}$-arylglycine esters. Reaction conditions for the indirect electrolysis: 1 ( $0.5 \mathrm{mmol}$ ), 2a $(0.6 \mathrm{mmol}), n-\mathrm{Bu}_{4} \mathrm{NI}(30 \mathrm{~mol} \%), 0.1 \mathrm{M} \mathrm{LiClO}_{4} / \mathrm{CH}_{3} \mathrm{CN}(5 \mathrm{~mL})$ and $\mathrm{CH}_{2} \mathrm{Cl}_{2}(10 \mathrm{~mL}), \mathrm{AcOH}(50 \mathrm{~mol} \%)$, current density $\left(3 \mathrm{~mA} / \mathrm{cm}^{2}\right)$, graphite anode and cathode, at room temperature; reaction conditions for direct electrolysis: $1(0.5 \mathrm{mmol}), 2 \mathrm{a}(0.6 \mathrm{mmol}), 0.1 \mathrm{M} \mathrm{LiClO} / \mathrm{CH}_{3} \mathrm{CN}(5 \mathrm{~mL})$ and CH $\mathrm{Cl}_{2}$ $(10 \mathrm{~mL}), \mathrm{AcOH}(50 \mathrm{~mol} \%)$, current density $\left(3 \mathrm{~mA} / \mathrm{cm}^{2}\right)$, graphite anode and cathode, at room temperature; yields in parenthesis obtained from direct electrolysis.

3ah-3aj likely derives from an azo-Diels-Alder reaction of styrene or ethynylbenzene with an imine intermediate, in situ generated from anodic oxidation of $\mathbf{1 a}$, followed by additional oxidation [32-36].

To prove the practicability of the protocol, a scaled-up reaction was also carried out. As illustrated in Scheme 4, when $6 \mathrm{mmol}$ of ethyl $p$-tolylglycinate (1a) was allowed to react with 1,3,5trimethoxybenzene (2a) under the standard conditions, adduct 3aa was isolated in a $75 \%$ yield, without obvious losing of yield.

To better understand the reaction mechanism, control experiments were performed. As shown in Scheme 5, the anodic oxidation of $1 \mathbf{a}$ in the absence of a $\mathrm{C}-\mathrm{H}$ nucleophile under the standard conditions gives imine intermediate product $\mathbf{5}$, which was detected by TLC and GC-MS. Moreover, when separated synthesized $\mathbf{5}$ was subjected to react with $\mathbf{2 a}$, the corresponding product 3aa was isolated in $89 \%$ yield. These control experiments indicate that $\mathbf{5}$ is a possible reaction intermediate.

Based on these control experiments described above, as well as related references [4], a plausible mechanism for the electrocatalytic cross dehydrogenative coupling of $\mathrm{N}$-arylglycine esters 1 with $\mathrm{C}-\mathrm{H}$ nucleophiles 2 is outlined in Scheme 6. The anodic oxidation of iodide generates the active species $\mathrm{I}_{2}$ or $\mathrm{I}^{+}$. Followed by a homogeneous reaction with $N$-arylglycine esters, $\mathrm{N}$-iodo intermediate 4 was generated. Eliminating a molecule of $\mathrm{HI}$ affords imine intermediate $\mathbf{5}$. In the presence of acetic acid, the protonated $5-\mathrm{H}^{+}$undergoes nucleophilic addition with $\mathrm{C}-\mathrm{H}$ nucleophiles $\mathbf{2}$ to give the desired products $\mathbf{3}$. 


\section{$\mathrm{C} / \mathrm{C}$ \\ $\mathbf{1 a}+\mathbf{2 b - 1} \underset{\substack{\mathrm{AcOH}(50 \mathrm{~mol} \%) \\ 3 \mathrm{~mA} / \mathrm{cm}^{2}}}{\stackrel{n-\mathrm{Bu}_{4} \mathrm{Nl}(30 \mathrm{~mol} \%)}{\longrightarrow}}$ 3ab-3aj}<smiles>CCOC(=O)C(C(=O)OCC)C(Nc1ccc(C)cc1)C(=O)c1ccccc1</smiles>

$3 a b 58 \%$<smiles>CCOC(=O)C(Nc1ccc(C)cc1)C(C(=O)OC)C(=O)OC</smiles>

3ac $34 \%$<smiles>CCOC(=O)C(Nc1ccc(C)cc1)C(C(=O)OCC)C(=O)OCC</smiles>

3ad $25 \%$<smiles>CCOC(=O)C(Nc1ccc(C)cc1)c1c(O)ccc2ccccc12</smiles>

3ae $52 \%$<smiles>CCOC(=O)C(Nc1ccc(C)cc1)c1c(O)ccc2ccc(O)cc12</smiles>

3af $58 \%$<smiles>CCOC(=O)c1cc(-c2ccc(C)cc2)c2cc(C)ccc2n1</smiles>

3ai $47 \%$ (form 1-methyl-4vinylbenzene)<smiles>CCOC(=O)C(Nc1ccc(C)cc1)c1c(O)ccc2cc(O)ccc12</smiles>

3ag $46 \%$<smiles>CCOC(=O)c1cc(-c2ccc(C)cc2)c2cc(C)ccc2n1</smiles>

3ai 45\% (form 1-ethynyl-4methylbenzene)<smiles>CCOC(=O)c1cc(-c2ccccc2)c2cc(C)ccc2n1</smiles>

3ah $64 \%$ (from styrene)<smiles>CCOC(=O)c1cc(-c2ccc(F)cc2)c2cc(C)ccc2n1</smiles>

3aj $50 \%$ (from 1-fluoro4-vinylbenzene)

Scheme 3: Scope of 2 using $n$-Bu $\mathrm{Bl}_{4} \mathrm{NI}$ as mediator. Reaction conditions:1a $(0.5 \mathrm{mmol}), 2(0.6 \mathrm{mmol}), n-\mathrm{Bu}_{4} \mathrm{NI}(30 \mathrm{~mol} \%), 0.1 \mathrm{M} \mathrm{LiClO} / \mathrm{CH}_{3} \mathrm{CN}(5 \mathrm{~mL})$ and $\mathrm{CH}_{2} \mathrm{Cl}_{2}(10 \mathrm{~mL}), \mathrm{AcOH}(50 \mathrm{~mol} \%)$, current density $\left(3 \mathrm{~mA} / \mathrm{cm}^{2}\right)$, graphite anode and cathode. Isolated yields are given.

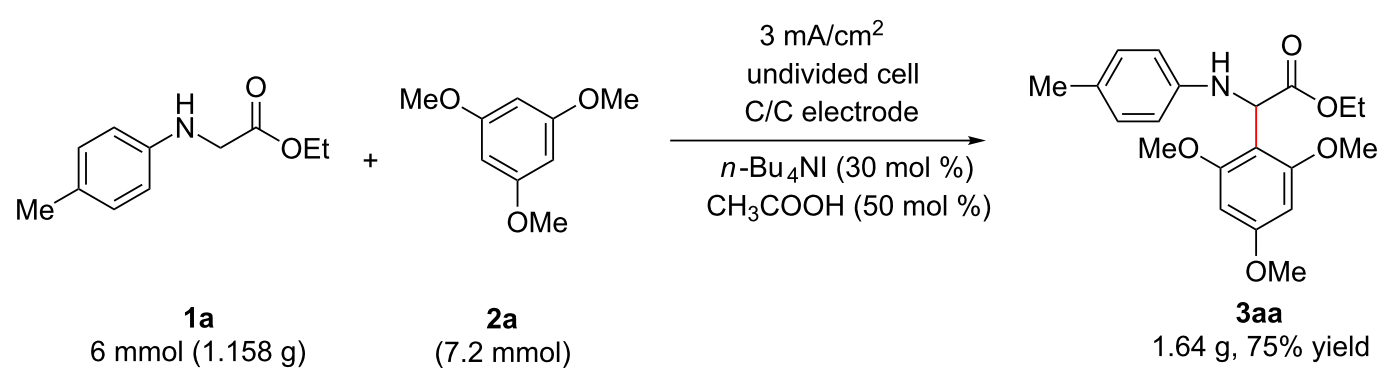

Scheme 4: Scaling up.

\section{Conclusion}

In summary, an efficient electrocatalytic cross dehydrogenative coupling of arylglycine esters with $\mathrm{C}-\mathrm{H}$ nucleophiles has been developed. This protocol employs simple $n$ - $\mathrm{Bu}_{4} \mathrm{NI}$ as the redox catalyst, avoiding utilization of transition metals and excess amounts of external oxidant, thereby providing an environmentally benign method to the $\mathrm{CDC}$ reaction. In addition, it was observed that the electrocatalytic process is superior to the direct electrolysis. Further application of this electrochemical protocol for the formation of new $\mathrm{C}-\mathrm{C}$ bonds is still on the way in our group.

\section{Experimental Instruments and reagents}

All melting points were measured with an electrothermal melting point apparatus and are uncorrected. NMR spectra were recorded using a $400 \mathrm{MHz}$ or $300 \mathrm{MHz}$ spectrometer $(400 \mathrm{MHz}$ ${ }^{1} \mathrm{H}$ frequency, $100 \mathrm{MHz}{ }^{13} \mathrm{C}$ frequency; $300 \mathrm{MHz}{ }^{1} \mathrm{H}$ frequen- 
<smiles>CCOC(=O)C=Nc1ccc(NCC(=O)OCC)cc1</smiles><smiles>CCOC(=O)/C=N/c1ccc(C)cc1</smiles>

$5(0.5 \mathrm{mmol})$<smiles>COc1cc(OC)cc(OC)c1</smiles>

2a $(0.6 \mathrm{mmol})$

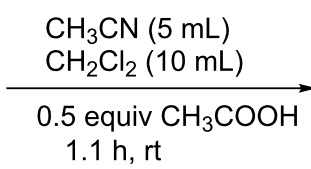

$1.1 \mathrm{~h}, \mathrm{rt}$<smiles>CCOC(=O)C(Nc1ccc(C)cc1)c1c(OC)cc(OC)cc1OC</smiles>

3aa $89 \%$

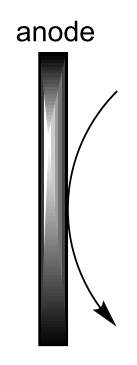
$\mathrm{I}_{2}$ or $\mathrm{I}^{\oplus}$<smiles>CC(O)C(C)C(O)O</smiles><smiles>[R7]C(=O)CN([13CH3])[14CH3]</smiles>

4<smiles>[R]OC(=O)CNC</smiles><smiles>C1=CCC=C1</smiles>
$\mathrm{Ar}^{-} \mathrm{N}$<smiles>[Y]NC(N)C(=O)O[Na]</smiles>

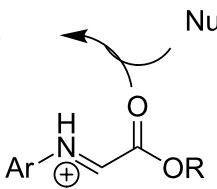
$5-\mathrm{H}^{+}$<smiles>[Te][Te]1CCCC1</smiles>

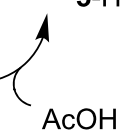
$\mathrm{AcOH}$

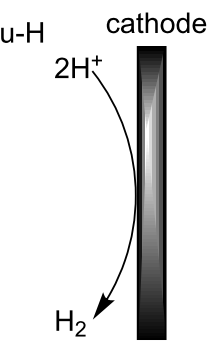

Scheme 6: A plausible mechanism for the electrocatalytic cross dehydrogenative coupling of $N$-arylglycine esters with $\mathrm{C}$-nucleophiles.

cy, $75 \mathrm{MHz}{ }^{13} \mathrm{C}$ frequency). Chemical shifts are given as $\delta$ values (internal standard: TMS). Coupling constants are reported in Hz. All starting materials and solvents were obtained from commercial sources and used without further purification. Products were purified by chromatography on silica gel (petroleum ether/EtOAc).

\section{Typical procedure for the electrocatalytic cross} dehydrogenative coupling of $\mathrm{N}$-arylglycine ester and $\mathrm{C}-\mathrm{H}$ nucleophiles

An undivided cell was equipped with a carbon anode $\left(2 \times 2 \mathrm{~cm}^{2}\right)$ and a carbon cathode $\left(2 \times 2 \mathrm{~cm}^{2}\right)$ and connected to a DC regulated power supply. To the cell was added $\mathrm{N}$-arylglycine ester $(0.5 \mathrm{mmol}), \mathrm{C}-\mathrm{H}$ nucleophiles $(0.6 \mathrm{mmol})$, $n$ - $\mathrm{Bu}_{4} \mathrm{NI}(0.15 \mathrm{mmol})$ and $5 \mathrm{~mL}$ of $0.1 \mathrm{M} \mathrm{LiClO}_{4} / \mathrm{CH}_{3} \mathrm{CN}$ and $10 \mathrm{~mL} \mathrm{CH}_{2} \mathrm{Cl}_{2}$. The mixture was electrolyzed using constant current conditions $\left(\approx 3 \mathrm{~mA} / \mathrm{cm}^{2}\right)$ at room temperature under magnetic stirring. When TLC analysis indicated that the electrolysis was complete (witnessed by the disappearance of the $N$-arylglycine ester), the solvent was removed under reduced pressure. The residue was poured into a saturated aqueous solution of $\mathrm{Na}_{2} \mathrm{~S}_{2} \mathrm{O}_{3}$ and the product was then extracted with DCM $(3 \times 20 \mathrm{~mL})$, dried over $\mathrm{Na}_{2} \mathrm{SO}_{4}$, and concentrated in vacuo. The residue was purified by column chromatography on silica gel using a mixture of petroleum ether/EtOAc $(\mathrm{v} / \mathrm{v}=3: 1)$ as eluent to afford the desired pure product.

Typical procedure for the direct electrochemical cross dehydrogenative coupling of $\mathrm{N}$-arylglycine ester and $\mathrm{C}-\mathrm{H}$ nucleophiles

The procedure was identical to that of electrocatalytic synthesis, but without the addition of $n$ - $\mathrm{Bu}_{4} \mathrm{NI}$ as the mediator.

\section{Supporting Information}

\section{Supporting Information File 1}

General procedure and analytical data.

[https://www.beilstein-journals.org/bjoc/content/ supplementary/1860-5397-14-35-S1.pdf] 


\section{Acknowledgements}

This work was supported by grants from the National Natural Science Foundation of China (No. 21472011, 21272021) and the National Key Technology R\&D Program (2017YFB0307502, 2011BAD23B01). ZCC also thank financial support from the Open Project Program of Beijing Key Laboratory of Flavor Chemistry, Beijing Technology and Business University (BTBU).

\section{ORCID ${ }^{\circledR}$ iDs}

Kun Xu - https://orcid.org/0000-0002-0419-8822

\section{References}

1. Girard, S. A.; Knauber, T.; Li, C.-J. Angew. Chem., Int. Ed. 2014, 53, 74. doi:10.1002/anie.201304268

2. Scheuermann, C. J. Chem. - Asian J. 2010, 5, 436. doi:10.1002/asia.200900487

3. Ritleng, V.; Sirlin, C.; Pfeffer, M. Chem. Rev. 2002, 102, 1731. doi:10.1021/cr0104330

4. Xu, H.-J.; Lu, Y.; Farmer, M. E.; Wang, H.-W.; Zhao, D.; Kang, Y.-S.; Sun, W.-Y.; Yu, J.-Q. J. Am. Chem. Soc. 2017, 139, 2200. doi:10.1021/jacs.6b13269

5. Jiang, H.; He, J.; Liu, T.; Yu, J.-Q. J. Am. Chem. Soc. 2016, 138, 2055. doi:10.1021/jacs.5b13462

6. Chatani, N.; Asaumi, T.; Yorimitsu, S.; Ikeda, T.; Kakiuchi, F.; Murai, S. J. Am. Chem. Soc. 2001, 123, 10935. doi:10.1021/ja011540e

7. Li, Z.; Li, C.-J. J. Am. Chem. Soc. 2005, 127, 6968. doi:10.1021/ja0516054

8. Condie, A. G.; González-Gómez, J. C.; Stephenson, C. R. J. J. Am. Chem. Soc. 2010, 132, 1464. doi:10.1021/ja909145y

9. Freeman, D. B.; Furst, L.; Condie, A. G.; Stephenson, C. R. J. Org. Lett. 2012, 14, 94. doi:10.1021/ol202883v

10. Hari, D. P.; König, B. Org. Lett. 2011, 13, 3852. doi:10.1021/ol201376v

11. Twyman, R. M. Principles of proteomics; BIOS Scientific Publishers: New York, 2004.

12. Zhao, L.; Li, C.-J. Angew. Chem., Int. Ed. 2008, 47, 7075. doi:10.1002/anie.200801367

13. Li, C.-J. Acc. Chem. Res. 2009, 42, 335. doi:10.1021/ar800164n

14. Xie, J.; Huang, Z.-Z. Angew. Chem., Int. Ed. 2010, 49, 10181. doi:10.1002/anie.201004940

15. Zhu, Z.-Q.; Bai, P.; Huang, Z.-Z. Org. Lett. 2014, 16, 4881. doi:10.1021/ol502402s

16. Salman, M.; Zhu, Z.-Q.; Huang, Z.-Z. Org. Lett. 2016, 18, 1526. doi:10.1021/acs.orglett.6b00162

17. Huo, C.; Wang, C.; Wu, M.; Jia, X.; Xie, H.; Yuan, Y. Adv. Synth. Catal. 2014, 356, 411. doi:10.1002/adsc.201300535

18. Gao, X.-W.; Meng, Q.-Y.; Xiang, M.; Chen, B.; Feng, K.; Tung, C.-H.; Wu, L.-Z. Adv. Synth. Catal. 2013, 355, 2158. doi:10.1002/adsc.201300311

19. Yang, X.; Li, L.; Li, Y.; Zhang, Y. J. Org. Chem. 2016, 81, 12433. doi:10.1021/acs.joc.6b02683

20. Sperry, J. B.; Wright, D. L. Chem. Soc. Rev. 2006, 35, 605. doi:10.1039/b512308a

21. Francke, R.; Little, R. D. Chem. Soc. Rev. 2014, 43, 2492. doi:10.1039/c3cs60464k

22. Horn, E. J.; Rosen, B. R.; Baran, P. S. ACS Cent. Sci. 2016, 2, 302. doi:10.1021/acscentsci.6b00091
23. Yang, Q.-L.; Li, Y.-Q.; Ma, C.; Fang, P.; Zhang, X.-J.; Mei, T.-S. J. Am. Chem. Soc. 2017, 139, 3293. doi:10.1021/jacs.7b01232

24. Schäfer, H. J. Angew. Chem., Int. Ed. 2017, 56, 15502. doi:10.1002/anie.201707804

25. Zhao, H.-B.; Hou, Z.-W.; Liu, Z.-J.; Zhou, Z.-F.; Song, J.; Xu, H.-C. Angew. Chem., Int. Ed. 2017, 56, 587. doi:10.1002/anie.201610715

26. Wang, P.; Tang, S.; Huang, P.; Lei, A. Angew. Chem., Int. Ed. 2017, 56, 3009. doi:10.1002/anie.201700012

27. Jiang, Y.; Xu, K.; Zeng, C. Chem. Rev. 2017, in press. doi:10.1021/acs.chemrev.7b00271

28. Li, W.-C.; Zeng, C.-C.; Hu, L.-M.; Tian, H.-Y.; Little, R. D. Adv. Synth. Catal. 2013, 355, 2884. doi:10.1002/adsc.201300502

29. Chen, J.; Yan, W.-Q.; Lam, C. M.; Zeng, C.-C.; Hu, L.-M.; Little, R. D. Org. Lett. 2015, 17, 986. doi:10.1021/acs.orglett.5b00083

30. Liang, S.; Zeng, C.-C.; Luo, X.-G.; Ren, F.-z.; Tian, H.-Y.; Sun, B.-G.; Little, R. D. Green Chem. 2016, 18, 2222. doi:10.1039/C5GC02626A

31. Kang, L.-S.; Luo, M.-H.; Lam, C. M.; Hu, L.-M.; Little, R. D.; Zeng, C.-C. Green Chem. 2016, 18, 3767. doi:10.1039/C6GC00666C

32. Ni, M.; Zhang, Y.; Gong, T.; Feng, B. Adv. Synth. Catal. 2017, 359, 824. doi:10.1002/adsc.201601066

33. Gandeepan, P.; Rajamalli, P.; Cheng, C.-H. Asian J. Org. Chem. 2014, 3, 303. doi:10.1002/ajoc.201300262

34. Xie, Z.; Jia, J.; Liu, X.; Liu, L. Adv. Synth. Catal. 2016, 358, 919. doi:10.1002/adsc.201501015

35. Liu, J.; Wang, Y.; Yu, L.; Huo, C.; Wang, X.; Jia, X. Adv. Synth. Catal. 2014, 356, 3214. doi:10.1002/adsc.201400005

36. Rohlmann, R.; Stopka, T.; Richter, H.; Garcia Mancheño, O. J. Org. Chem. 2013, 78, 6050. doi:10.1021/jo4007199

\section{License and Terms}

This is an Open Access article under the terms of the Creative Commons Attribution License (http://creativecommons.org/licenses/by/4.0), which permits unrestricted use, distribution, and reproduction in any medium, provided the original work is properly cited.

The license is subject to the Beilstein Journal of Organic Chemistry terms and conditions:

(https://www.beilstein-journals.org/bjoc)

The definitive version of this article is the electronic one which can be found at: doi:10.3762/bjoc. 14.35 